\title{
Huntington's Disease: prenatal screening for late onset disease
}

\author{
Stephen G Post Case Western Reserve University, Cleveland, Ohio
}

\section{Author's abstract \\ This article presents a set of moral arguments regarding the selective abortion of fetuses on the basis of prenatal screening for late onset genetic diseases only, and for Huntington's Disease ${ }^{\star}$ in particular. After discussion of human suffering, human perfection and the distinctive features of the lives of people confronting late onset genetic disease, the author concludes that selective abortion is difficult to justify ethically, although it must remain a matter of personal choice.}

Prenatal screening will increasingly be capable of detecting late onset diseases. Women will be making more and more decisions about whether to abort fetuses with late onset genetic diseases. Huntington's Disease is just one such disease that is clearly testable already and as we continue to map the human genome, there will be many others. While selective abortion is an old topic, the projected magnitude of screening possibilities raises it anew. I will argue that selective abortion for late onset diseases such as Huntington's Disease is difficult to justify morally.

I have no interest in arguing against abortion rights; certainly in a society that permits abortion on demand legal restrictions on selective abortion make no sense. Women have the right to choose abortion. However, this still leaves room for discussion of the moral considerations that might inform individual conscience as this right is exercised. I also have no interest in questioning selective abortion for grave or relatively serious genetic defects that will manifest immediately or early in life.

However, selective abortion for trivial or moderately serious genetic indications, and for indications that will manifest only later in life, raise serious moral concern (1).

\section{^Editor's note}

In this and the following paper, Huntington's Disease has been used throughout for consistency, replacing

Huntington's Chorea, except in references where the latter term is part of the title of a paper.

\section{Key words}

Huntington's Disease; selective abortion; late onset; suffering; perfection.
For instance, it has been argued that the medical profession should abandon a position of ethical neutrality with regard to prenatal sex selection, because this sets morally questionable precedents for the future, when testing will indicate eye or hair colour, body build, and so forth (2).

Prenatal testing will eventually be capable of detecting thousands of single gene defects, many more polygenic and multifactorial defects, and numerous superficial data of aesthetic concern. This extensive new level of knowledge will inevitably lead to tremendously complex personal choices about what lives are worth living, qualitatively considered.

In the absence of an obviously grave defect, decisions will be made, presumably on the basis of three factors: severity, probability, and age of onset of disease or disability. Turner's syndrome, for instance, affects girls, resulting in shortness, infertility, and often odd appearance (for example, web-neck and shield chest). However, life expectancy is normal, and with in vitro fertilisation it has become possible for certain Turner's cases to have babies. Probability of occurrence is clear, as is age of onset, but the severity of the syndrome might not be considered great. The difficulty, ethically, comes with parental decisions about the acceptability of the child's quality of life. Another example would be adult onset polycystic kidney disease, which may or may not occur, and which results in progressive renal failure during the adult years $(3,4)$. It is, of course, treatable by dialysis or transplant. In this example, moderate severity combines with uncertainty of manifestation and late onset. Huntington's Disease can be distinguished from adult onset polycystic kidney disease because it is much more severe, and untreatable (5).

My scope here is limited to the concrete case of Huntington's Disease, albeit that the two humanistic themes I develop obviously apply more generally. These themes are meant to put parental choices for selective abortion in perspective. They are (i) the parental desire to avoid bringing suffering into the world, and (ii) the ambiguity of desiring 'perfect' babies. I worry that our culture may be succumbing to the conceptually flawed presuppositions that the physical-bodily level of human existence is the final 
defining ground of perfection, and that suffering can be whitewashed out of the human predicament. Of course suffering remains and will remain despite medicine, as every clinician knows. However, medical advance inevitably contributes to the cultural expectation that at least physical suffering can be gotten rid of. From these humanistic themes, I will turn directly to the case of Huntington's Disease, and argue it is a morally inappropriate basis for a decision selectively to abort.

\section{The suffering of offspring}

Parents naturally prefer not to bring lives filled with suffering into the world. Few would quarrel with the assumption that it is preferable to have healthy children who are not born into severe or chronic pain. When prenatal diagnosis reveals a grave defect that will manifest early and result in a life of onerous suffering, non-malfeasance warrants selective abortion. This is non-controversial to the great majority of people, albeit that there are some extremists who condemn all selective abortions categorically. While I disagree with the extremists, I think they serve a purpose by reminding us that selective abortion for even the best reasons does involve the act of ending a potential human life and therefore demands an attitude of moral seriousness, if not of compunction.

But selective abortion for significant early onset diseases affirmed, I hasten to add that unusual degrees of suffering are not the necessary result of many genetic defects and that lives with degrees of physical suffering can be highly creative as well as deeply meaningful.

Fyodor Dostoyevsky, for instance, suffered from seizure disorder. In a letter to the famous critic Nikolai Strakhov, he wrote these remarkable words: 'For a few moments before the fit, I experience a feeling of happiness such as it is quite impossible to imagine in a normal state and which other people have no idea of. I feel entirely in harmony with myself and the whole world, and this feeling is so strong and so delightful that for a few seconds of such bliss one would gladly give up ten years of one's life, if not one's whole life' (6). This passage is striking because it powerfully suggests that there can be less suffering in the experience of an illness than observers might think. In the case of people with retardation, for instance, there is no reason to assume that they suffer simply because of their retardation (they may suffer due to social stigma).

A feminist advocate of rights for disabled persons points out that as prenatal diagnosis results in vast new genetic knowledge, women need 'to obtain far more and very different information than they very commonly get about people with disabilities' (7). In many cases, negative stereotypes obscure the creative ways that disabled people cope with challenges. With our societal inclination to rigid standards of beauty and physical prowess, self-reliance and productivity, it is assumed that those who fall short of these standards therefore must suffer. This assumption is flawed (8).
Furthermore, the desire to avoid suffering must be tempered by the recognition that suffering is a part of all human lives, to a greater or lesser degree (9). One need not be a Buddhist to acknowledge the futility of efforts entirely to avoid suffering. Take the case of the French artist, Henri de Toulouse-Lautrec. A descendant of aristocrats, he was the victim of two accidents which broke his legs and left him incurably disabled. His torso developed, but not his legs. His was an irregular life, one of immense suffering; it was also one of creative compensation. Lautrec was born a normal infant, for all intents and purposes a 'perfect baby'. But the contingencies of human experience which include accident left him disabled anyway, and suffering from a diminutive stature. Even then, his life was meaningful to him, albeit that he died in an asylum (10).

Oriental philosophers would probably refer here to the human inclination for control. They would recite from Taoist texts about the old man and the horse. There was an old man who had a horse. One day the horse ran away. The neighbours came and said: 'Old man, old man, how unfortunate'. He responded: 'How do you know?'. The next day, the horse returned with two other wild horses beside it. The neighbours said: 'Old man, old man, how fortunate'. 'How do you know?' he answered. His beloved son went riding on one of the new stallions, and was badly thrown, breaking his leg. The neighbours said: 'Old man, old man, how unfortunate'. He responded: 'How do you know?'. At that time, as it turned out, many young men were being drafted into a work-force to build the great wall of China. Most of them died. The old man's son was too crippled to go. The neighbours said: 'Old man, old man, how fortunate'. His only answer was: 'How do you know?'.

This is a story designed to express the extent to which we cannot control human events, much less predict what sufferings will flow from them. Now that we have the technology to control genetic defects, we must not forget the basic reality of human suffering.

\section{Perfectionism}

The right of only 'perfect babies' to exist is not a matter of public policy but each time a selective abortion for a moderate or trivial imperfection occurs, we are in effect accepting this principle. All perfectionism must be tempered by an awareness of what Leslie A Fiedler dubs 'the tyranny of the normal' (11). Fiedler notes a 'deep ambivalence toward fellow creatures who are perceived at any given moment as disturbingly deviant, outside currently acceptable physiological norms' (12). He refers to 'a vestigial primitive fear of the abnormal, exacerbated by guilt'. Fiedler fears the 'enforced physiological normalcy' that sent dwarfs to extermination camps in Hitler's Germany. 'Perhaps it is especially important for us to realise that finally there are no normals, at a moment when we are striving desperately to eliminate freaks, to normalise the world' (13). 
One of the ways in which persons who depart from 'normals' contribute to the community is by challenging us to overcome social stigmas, and to accept difference in our midst. Views of physiological human perfection are inevitably intertwined with stigmas, one form of which is 'abominations of the body' (14). Those whose bodies depart negatively from the 'normals' are the victims of a socially shaped tendency to revulsion. Stigmas specific to the body are as morally problematic as those related to religion, race, and nationality and of ten cause great suffering to disabled people. People who are different and 'imperfect' teach us about the meaning of equality and commitment. But we are beings who fear difference, so diversity is hard to sustain.

The very nature of human perfection has, of course, been the subject of acrimonious debate over the centuries. In the mediaeval period, there was a profound sense that perfection is chiefly a matter of character and virtue, and that bodily imperfections provide opportunities for concentration on the internal moral and spiritual values. Indeed, the weight of religious symbolism, from the club-footed Christ figure of the Eastern Orthodox icons to Dostoyevsky's idiot epileptic saviour, underscores the possibilities for inward perfection despite external limitations.

There is treasure in earthen vessels, and earthen vessels we humans are, subject to countless infections, accidents, chronic ailments, and finally to the decline of old age and death that we in this culture try so hard to deny, as though senility were mere myth. It is in the dialectic between bodily decline and growth in character that Dostoyevsky suggests we find what perfection is possible to us. Of course it is reasonable to avoid bringing grave human imperfection into the world. Infants with no relational potential should not be born. But we must be circumspect about declaring too imperfect those who must endure, especially later in life, the very sorts of frailties that eventually assault each one of us.

How do we determine what defects are severe enough to warrant termination of embryonic life due to imperfection? It might seem far-fetched that selective abortion would be chosen based on susceptibility to disease in the distant future, 'but social mores change rapidly in the face of new technology' (15). Prenatal testing may encompass everything from eventual susceptibility to familial Alzheimer's disease to body structure. As it has been put: 'Our increasing ability to control our reproduction and to determine prenatally the genetic endowment of our children changes both the practice of medicine and the concept of humanness' (16). Whether, with vast new genetic knowledge, our reproductive lives, our tolerance of difference, our acceptance of human finitude, and our communities will be better off still remains to be seen.

\section{Huntington's Disease}

Huntington's Disease usually manifests between the ages of thirty and fifty. It is clearly a severe disease, even insidious. Personality changes, choreic movements, paranoid reactions, cognitive impairment, and dementia are just some of the phenomena that occur. The illness can last for a decade or slightly more, resulting eventually in death. L M Purdy writes thus: 'For devastating diseases like Huntington's Disease, this part of the judgement should be unproblematic: no one would want a loved one to suffer so' (17). Certainly not. However, I dispute Purdy's argument that, from the child's point of view, it is unethical not to abort. The child, he claims, deserves an 'opportunity for a good life'.

Contra Purdy, I hold that a life of thirty to fifty years' duration is potentially a fully good one. The meanings and experiences that so many years afford could easily surpass those who live to old age but suffer from despair and purposelessness. The suffering brought on as symptoms manifest is severe, but not categorically more so than is the case with the dementias that afflict many elderly people. Pre-emptive suicide, while not something I would champion, is at least an option (18). Comfort and palliation, along with compassion, can mitigate suffering.

It is morally presumptuous to argue that from the child's perspective, life with Huntington's Disease is wrongful. From the parental viewpoint, if they may live long enough to witness the manifestation of the disease, they are not burdened in anything like the same way that the parents of children with early onset diseases such as Down's syndrome might be. They will not face the care-giver burdens that sometimes make the lives of parents with severely retarded children onerous.

Of course parents have a right selectively to abort in the case of prenatal diagnosis of probable Huntington's Disease. I only contend that ethically, the grounds for such abortions are thin at best. Parents want to avoid bringing suffering into the world, but they can never fully accomplish this to begin with, as I have argued previously. Parents want 'perfect babies', but how does one measure perfection, and what levels of fulfilment are open to those who may be eventual victims of mid- or late-onset diseases?

My intent has been to raise questions about selective abortion for even severe late-onset diseases. There is, of course, room for conscientious disagreement in most ethical debates. However, abortion for Huntington's Disease is extremely difficult to justify.

Stephen G Post is Associate Professor of Biomedical Ethics in the Centre for Biomedical Ethics, the School of Medicine, Case Western Reserve University, Cleveland, Ohio. He holds appointments in the Departments of Philosophy and Religious Studies as well.

\section{References}

(1) Robertson J A. Procreative liberty and human genetics. Emory law journal 1990; 39: 697-719.

(2) Wertz D C, Fletcher J C. Fatal knowledge? Prenatal 
diagnosis and sex selection. Hastings Center report 1989; 19: 21-27.

(3) Reeders S T, Breuning M H, Corney G et al. A highly polymorphic DNA marker linked to adult polycystic kidney disease on chromosome 16. Nature 1985; 292: 851-853.

(4) Kimberling W J, Fain P R, Kenyon J B et al. Linkage heterogeneity of autosomal dominant polycystic kidney disease. New England journal of medicine 1988; 319: 913918.

(5) Gusella J F, Wexler N S, Conneally P M et al. A polymorphic DNA marker genetically linked to Huntington's Disease. Nature 1983; 306: 234-238.

(6) Dostoyevsky F. The idiot. New York: Penguin, 1955 [original 1870]: 8.

(7) Asch A. Can aborting 'imperfect' children be immoral? In: Arras A, Rhoden N, eds. Ethical issues in modern medicine. Mountain View, California: Mayfield Publishing, 1989: 319-321.

(8) Saxon M. Prenatal screening and discriminating attitudes about disability. In: Baruch $\mathrm{E} \mathrm{H}$, D'Adama $\mathrm{A}$ F, Seager J, eds. Embryos, ethics, and women's rights: exploring the new reproductive technologies. New York:
Haworth Press, 1988: 217-224.

(9) Hauerwas S. Suffering presence. Notre Dame: University of Notre Dame Press, 1986.

(10) Craven T. A treasury of art masterpieces. New York: Simon and Schuster, 1939: 518.

(11) Fiedler L A. The tyranny of the normal. In: Murray T H, Caplan A L, eds. Which babies shall live? Humanistic dimensions of the care of imperiled newborns. Clifton, New Jersey: Humana Press, 1985: 151-159.

(12) See reference (11): 152.

(13) See reference (11): 157

(14) Goffman E. Stigma: notes on the management of spoiled identity. New York: Simon and Schuster, 1986.

(15) Bishop J E, Walsholz M. Genome. New York: Simon and Schuster, 1990: 20.

(16) Elias S, Annas G J. Reproductive genetics and the law. Chicago: Year Book Medical Publishers, 1987: xi.

(17) Purdy L M. Genetic diseases: can having children be immoral? In: Munson R, ed. Intervention and reflection: basic issues in medical ethics. Belmont, California: Wadsworth Press, 1988: 364-371.

(18) Prado C G. The last choice: pre-emptive suicide in advanced age. Westport, Connecticut: Greenwood Press, 1990. 